\title{
THE PERCEPTIONS OF STUDENTS AND LECTURERS ON THE LIVE STREAMING OF LECTURES AS AN ALTERNATIVE TO ATTENDING CLASS
}

\section{Rossouw}

School of Accountancy

Stellenbosch University

Stellenbosch, South Africa

e-mail: marelir@sun.ac.za

\section{ABSTRACT}

Rising student numbers and unpredictable unrest situations on campuses in South Africa have begged for alternatives to (or substitutes for) physical class attendance to address these problems. This study aimed to test student and lecturer perceptions on live streaming as a possible alternative at a South African university. Questionnaires were distributed to collect primary data. Students and lecturers agreed quite strongly that class attendance plays a big role in students achieving academic success. It is therefore crucial for the teaching functionality to continue at all times, whether physically or streamed. Participants agreed that the most popular argument why students would be interested in live streaming is the convenience of their own space, while the high cost of data would deter them from using it. Comments from participants revealed the need for live-streamed classes to be recorded and made available to them afterwards. A correlation was found between students' self-rated technological ability and their willingness to live-stream classes. Students with better technological skills are more willing to make use of live-streaming facilities. Approximately 90 per cent of student participants in this study would make use of livestreaming facilities. Lecturers, on the other hand, were less excited about the prospect of volunteering for their classes to be streamed. Their willingness to stream, however, is not dependent on their technological ability, but rather on their personal preference regarding teaching and learning.

Keywords: live streaming, lectures, perceptions, tertiary institutions

\section{INTRODUCTION}

Tertiary institutions are experiencing rapid increases in student numbers, and the complexities this brings have been exacerbated by unrest on campuses throughout South Africa as a result of the campaign for free higher education and the subsequent pressure to manage student fees. These factors have contributed towards tertiary institutions having to come up with innovative ways to ensure that teaching and learning can continue undisturbed. Alternative ways are explored to reach (and teach) students. One of the innovations that universities are investigating 
(and have adopted) is live-streaming lectures. However, limited research has been published on the perceptions of students and lecturers on live streaming at a South African university. Livestreamed lectures provide a viable alternative for lectures to continue, especially during times of unrest on campus, but also as an alternative for students who prefer to attend class from the comfort of their own home as opposed to a classroom environment. The current generation of students at tertiary institutions spend hours a day using technology. Live streaming as an alternative to attending class physically therefore also aligns with "already-tech-savvy" students' ability and willingness to interact with technology for their learning experience at tertiary institutions.

\section{LITERATURE REVIEW}

The Department of Higher Education and Training (DHET) has previously reported on the number of first-time entering undergraduate students at public higher education institutions. The number of students has increased dramatically from 98095 in 2000 to 143024 in 2014 (an increase of approximately 46\%) (DHET 2017). Universities do not necessarily have the means to expand their infrastructure to accommodate the continued rise in student enrolments. Improvements to infrastructure, however, have been proven to increase student satisfaction and student evaluations of their lecturers (Hill and Epps 2010, 77). In cases where universities do not have the means to increase their classroom capacity, classes may become congested spaces where too many students are allocated to one venue. The need for wider accessibility to higher education is constantly being underlined (De Villiers 2017). Sader and Gabela (2017, 238) report that overcrowded classes lead to diluted student participation based on their research on widening the academic participation of students. Students who do not attend their classes because lecture halls are too full are not helping the throughput rate of delivering graduates within their degree period. If students fail as an indirect result of overcrowded classrooms, this places even more pressure on already overcrowded classes.

Fraser and Killen (2003, 257-258) emphasise the importance of attending lectures. Their study tested academic success and failure factors as viewed by lecturers and first-year students at the University of Pretoria. Both groups of participants ranked attendance of lectures within the top 10 academic success factors. Correspondingly, both groups also ranked irregular attendance of lectures within the top 10 failure factors. Students at Stellenbosch University also attested to the importance of class attendance for good performance (Van Schalkwyk, Menkveld and Ruiters 2010, 634). Gerber, Mans-Kemp and Schlechter $(2013,270)$ conclude in their study that students who fully engage with the academic activities of their module by attending classes and submitting assignments of a high standard, will in all likelihood perform 
better than students who are less engaged.

October 2015 saw one of the biggest and most effective student campaigns in post-1994 South African history with students protesting against the proposed increase in student fees (Cloete 2015). The affected universities responded in various ways and most were ultimately able to complete their academic programmes within the 2015 calendar year. However, students at one of the campuses of the North-West University (NWU) could not start their classes at the beginning of 2016 due to the campus being closed as a result of the continued unrest. This led to the Association of Black Accountants of SA (ABASA) organising a camp for affected students during the Easter period of that year (Weidemann 2016, 9).

Even though the literature shows that class attendance promotes good performance, the contrary may be true if classrooms are overcrowded or perceived as spaces where learning cannot be optimised. Students may also feel that it is unsafe to attend class (or be barred from class) as a result of unrest on campus and therefore choose not to attend class physically in such times. An alternative to the traditional classroom environment at tertiary institutions (i.e. attending class physically) is necessary in order to overcome these problems. One alternative, as organised by ABASA for students at NWU, could be to provide a safe environment or to arrange a new venue where students can attend lectures to catch up on lost work. However, this will inevitably lead to extended logistical arrangements and additional cost. Moreover, the time lost between the intended class and the alternative arrangement could result in timetable clashes or exam interference. A more feasible alternative could be live streaming of lectures. For the purpose of this article, live streaming means that the event (lecture) is broadcast to an audience (students) in real time. Depending on the platform used to broadcast the event, it may be possible to record the broadcast for use at a later stage. With recording and replaying functionalities, live streaming becomes video streaming, that is replaying the event as one would do with a video.

\section{ARGUMENTS FOR AND AGAINST THE LIVE STREAMING OF LECTURES}

Differing outcomes have been reported for the use of streaming facilities in tertiary education (in various fields of study). An earlier study by Wilson, Schenck and Grobler $(2000,91)$ found video conferencing sessions to be of value, whereas Mokoena $(2011,147)$ found that students in a distance learning environment became more negative towards video-conferencing after their participation in their study. Live streaming might also be well received by students, but in reality lead to weaker performance and create "lonely students" who do not interact with the rest of their class (Fredriksen 2015, 51). Upon further investigation, it was noted that there are various reasons why students would make use of live-streaming facilities (hereafter referred to 
as "arguments for"), and many reasons why they would not (hereafter referred to as "arguments against").

A study testing students' perceptions of video streaming in nursing education showed "convenience" and "increased learning of content" as the two biggest arguments for video streaming (Wall Parilo and Parsh 2014, 162). The fact that video streaming allows for lectures to be recorded (thus having the functionality of pausing a lecture when it is being replayed) was especially underlined by students in their commentary. Live streaming, however, might not have the option of pausing a lecture. The same study also tested students' reasons for enjoying live lectures, in other words physically attending class. They listed "faculty connection", "student interaction" and "ability to clarify questions" as the three main reasons why they enjoyed physical lectures. These reasons are considered to be arguments against live streaming. Faculty connection can be translated as students enjoying the interaction with their lecturer when they attend classes physically. Abdous and Yen $(2010,249)$ confirm that the interaction between lecturers and students has a big influence on student satisfaction and success. Correspondingly, Bollinger and Martindale $(2004,65)$ found instructor-related matters to be the biggest contributor towards student satisfaction levels for online courses. These studies suggest that the lecturer plays a big role in both environments: physical classroom as well as remote online learning. On the other hand, Fraser and Killen's (2003) study found that firstyear students have reason to believe that lecturers may contribute towards their academic failure. First-year students listed the following three statements (which were listed among the top 10 out of 55 possible statements that may lead to academic failure) pertaining to lecturers as negative factors in a physical classroom context: "boring presentations by lecturers", "badly structured presentations by lecturers" and "poor language ability of lecturers" (Fraser and Killen $2003,258)$. If students are negative about their lecturer, they may opt for lectures to be streamed instead of attending class physically.

Another study (which focused more on lecturers' perceptions) on new technological advances in education has shown that lecturers may refrain from new teaching techniques (especially relating to technology) for fear that if might not work sufficiently (Webster and Son $2015,89)$. The researchers concluded that lecturers at tertiary institutions tend to follow the same lecturing techniques that their lecturers used when they were students. Other arguments in favour of live-streaming lectures, as mentioned in the literature review, are overcrowded classrooms (Sader and Gabela 2017, 238) as well as outdated infrastructure (Hill and Epps 2010, 77).

Webster and Son $(2015,92)$ made the observation that students were "relieved to turn on their phones upon leaving their class" as opposed to the monotonous nature of lectures by 
traditional chalkboard and textbook learning. The current generation of students, being used to working with (and being around) technology from an early age, may therefore be inclined to prefer live-streamed classes instead of attending it physically. Even though the content would still be the same, attending class from their own environment and through a technology platform might spark more interest. Koroghlanian and Brinkerhoff $(2008,235)$ report that students who take courses online have good (self-rated) computer skills, while Sahin and Shelley $(2008,220)$ report that students with good computer skills found online courses more enjoyable. Owens, Hardcastle and Richardson $(2009,70)$ investigated the inverse and concluded that students with less experience with technology reported more dissatisfaction with online learning. Interestingly enough, however, Abdous and Yen $(2010,255)$ found a negative relationship between students' self-rated computer skills and their satisfaction levels. Students who rated their computer skills as high in that study showed decreased satisfaction with distance education (an umbrella term that includes live or video streaming of lectures).

Additional arguments for or against live streaming could relate to practicalities. Many students who attend classes at tertiary institutions might not live on (or near) campus and therefore have to commute to class. On days when their transportation fails, live streaming could be an attractive option for these students to ensure that they don't fall behind. Students sometimes have timetable clashes as a result of repeating an academic year. If live-streamed classes are also recorded, this could be a great way for repeating students to catch up on lost work. On the other hand (and especially in a third world context), the cost of data is expensive and internet connectivity is not always guaranteed. If students have to live-stream classes from their own devices, the high cost of live streaming might deter them from using this functionality. Students may opt to attend classes physically due to the risk of losing their internet connectivity at home and then having to catch up on the work anyway.

The arguments for or against live-streaming lectures presented in this study are based on existing literature and the (limited) practical arguments explored. These arguments are summarised in Table 1. The arguments against live streaming also exist due to a preference for a physical classroom experience.

Table 1: Arguments for and against the live streaming of lectures

\begin{tabular}{|l|l|l|l|}
\hline \multicolumn{2}{|c|}{ Arguments for live streaming } & \multicolumn{1}{c|}{$\begin{array}{c}\text { Arguments against live streaming (moreover, a } \\
\text { preference for physical lectures) }\end{array}$} \\
\hline \multicolumn{1}{|c|}{ Argument } & Argument is based on & \multicolumn{1}{c|}{ Argument } & \multicolumn{1}{c|}{ Argument is based on } \\
\hline Overcrowded classes & Sader and Gabela 2017 & Technology failure & Webster and Son 2015 \\
\hline $\begin{array}{l}\text { Convenience (own } \\
\text { space) }\end{array}$ & $\begin{array}{l}\text { Wall Parilo and Parsh } \\
2014\end{array}$ & $\begin{array}{l}\text { Social aspect (going to } \\
\text { class with friends) }\end{array}$ & $\begin{array}{l}\text { Wall Parilo and Parsh } \\
\text { 2014; Fredriksen 2015 }\end{array}$ \\
\hline Boring class (theory) & $\begin{array}{l}\text { Fraser and Killen 2003; } \\
\text { Webster and Son 2015 }\end{array}$ & $\begin{array}{l}\text { Cannot pause live } \\
\text { streaming }\end{array}$ & Wall Parilo and Parsh 2014 \\
\hline
\end{tabular}




\begin{tabular}{|l|l|l|l|}
\hline \multicolumn{2}{|c|}{ Arguments for live streaming } & \multicolumn{1}{c|}{$\begin{array}{c}\text { Arguments against live streaming (moreover, a } \\
\text { preference for physical lectures) }\end{array}$} \\
\hline \multicolumn{1}{|c|}{ Argument } & Argument is based on & \multicolumn{1}{c|}{ Argument } & \multicolumn{1}{c|}{ Argument is based on } \\
\hline Dislike lecture venue & Hill and Epps 2010 & $\begin{array}{l}\text { Questions go } \\
\text { unanswered }\end{array}$ & Wall Parilo and Parsh 2014 \\
\hline Dislike lecturer & Fraser and Killen 2003 & $\begin{array}{l}\text { Prefer personal contact } \\
\text { with lecturer }\end{array}$ & $\begin{array}{l}\text { Wall Parilo and Parsh } \\
\text { 2014; Abdous and Yen } \\
\text { 2010 }\end{array}$ \\
\hline $\begin{array}{l}\text { Focus better when } \\
\text { alone }\end{array}$ & $\begin{array}{l}\text { Wall Parilo and Parsh } \\
2014\end{array}$ & $\begin{array}{l}\text { Focus better in class } \\
\text { (distracted at home) }\end{array}$ & $\begin{array}{l}\text { Focus is dependent on } \\
\text { each student's individual } \\
\text { preference. The argument } \\
\text { is entered to accommodate } \\
\text { the opposite preference. }\end{array}$ \\
\hline Timetable clash & Practicality & Data is expensive & Practicality \\
\hline $\begin{array}{l}\text { Location (live far from } \\
\text { campus) }\end{array}$ & Practicality & Internet connectivity & Practicality \\
\hline
\end{tabular}

\section{RESEARCH METHODOLOGY}

\section{Research objective, questions and contributions}

The objective of this research is to test student and lecturer perceptions on the live streaming of lectures. The following research questions have been developed from the literature review:

1. Do students and lecturers have different opinions on the matters affected by the live streaming of lectures?

2. What do students and lecturers perceive as the most important factors that contribute to a student's decision for or against the live streaming of lectures?

3. Is there a relationship between participants' self-rated technological level and their willingness to make use of live-streaming facilities?

The main contribution of this research is that it examines whether students and lecturers perceive live streaming of lectures to be a viable alternative for physical class attendance. It could be a welcome substitution at times of unrest on campus when students feel unsafe (or are prohibited) to attend lectures. It could also be an option for consideration if the increase in student numbers can no longer be accommodated by the existing infrastructure, or if students prefer watching a live-streamed lecture above physical class attendance for their learning experience at tertiary institutions.

\section{Research design and data collection}

The research design is empirical in nature. Questionnaires were designed based on the literature review in order to generate primary data. The study was conducted at Stellenbosch University (SU) in the Economic and Management Sciences (EMS) Faculty. The EMS Faculty at SU was 
considered an appropriate target location seeing that they have been encountering rising student numbers and experienced unrest on campus in 2015, which led to academic activities being suspended for a week (Anon 2016, 26). At the time of this study, live streaming is also not considered to be common practice at SU. First-year enrolments in the EMS Faculty have increased from approximately 1100 in 2012 to 1500 in 2016 (Stellenbosch University 2015, 2016). This study targeted two focus groups. The first focus group was first-year accounting students who are studying towards a Chartered Accountant (South Africa) (CA (SA)) designation. This will be referred to as Focus Group 1. The other group, referred to as Focus Group 2, was made up of lecturers at the School of Accountancy at SU. The opinions of these groups were tested against the literature to confirm whether previous findings can also be applied to a young generation CA (SA)'s. The results of the two groups were also compared to determine how students and lecturers at SU respectively perceive the possibility of livestreaming lectures.

Apart from biographical and background information, all other questions in the questionnaires were exactly the same for both focus groups. The questionnaire design was similar to that of Fraser and Killen (2003). Closed-ended Likert-scale questions were categorised into six major groupings, namely strongly agree, agree, neutral, disagree, strongly disagree and a preference not to answer. Questions where ranking orders were applied were also closed-ended. The ranking questions included a range of eight items to rank, with an option of choosing one item as not being valid.

A hyperlink to the first questionnaire was e-mailed to 620 students in Focus Group 1. This questionnaire was available for six days. Another link to the second questionnaire was emailed to 72 lecturers in Focus Group 2 and it was available for three weeks. Participation in the study was voluntary and participants remained anonymous. Ethical clearance and institutional permission were obtained from the relevant authorities.

\section{Statistical analysis}

Data collected from both focus groups were subjected to analysis of variance (ANOVA) tests. All responses pertaining to the live streaming of lectures were analysed by using the Statistica software programme. The responses analysed included Likert-scale statements to answer Research Question 1, arguments for and against live-streaming lectures to answer Research Question 2, and lastly a comparison between participants' self-rated technology level and their willingness to live-stream lectures to answer Research Question 3. A 5 per cent significance level was applied to all data analysed $(\mathrm{p}=0.05)$.

Statements in Likert-scale format, the arguments for and against live-streaming as well as 
self-rated technological ability were analysed by attaching values to each response. A Likertscale opinion of "strongly agree" was awarded a value of 5 and "strongly disagree" was awarded a value of 1 . A participant's choice not to answer a Likert-scale statement was ignored. An F-test followed to analyse the Likert-scale opinions of both focus groups and to determine the level of significance. The questionnaire to both focus groups included eight arguments for and eight arguments against the live streaming of lectures. The questionnaire asked participants to rank both sets of arguments from most popular to least popular. Mean ratings were determined for each item that was available for ranking. Both the "for" and "against" livestreaming arguments were ranked from 1 , being the most popular argument, to 8 , the least popular argument. If a participant chose any argument as not being valid, this argument obtained a score of 8 (which is also considered to be the least attractive argument on the list). After the ANOVA test, the results of the two focus groups were compared to determine whether a significant difference existed. Both focus groups were also asked to rate their own technological ability from 1 (very strong technologically) to 5 (bad with technology) to determine whether a correlation existed between the level of technological ability and a willingness to make use of live-streaming facilities. A two-way ANOVA was done for this test.

\section{RESEARCH FINDINGS}

The questionnaire for Focus Group 1 was completed by 134 participants, representing a 21.61 per cent response rate. The questionnaire for Focus Group 2 was completed by 49 participants, representing a 68.06 per cent response rate. The demographics of the two groups are analysed in Table 2.

Table 2: Participant demographics

\begin{tabular}{|l|l|c|c|c|c|}
\hline \multirow{2}{*}{ Category } & \multirow{2}{*}{ Options } & \multicolumn{2}{c|}{ Focus Group 1 } & \multicolumn{2}{c|}{ Focus Group 2 } \\
\cline { 3 - 6 } & & $\mathbf{n}$ & \% & $\mathbf{n}$ & \% \\
\hline Gender & Female & 79 & 58.95 & 34 & 69.39 \\
\hline & Male & 54 & 40.30 & 15 & 30.61 \\
\hline & No answer & 1 & 0.75 & & \\
\hline Age & 18 and younger & 32 & 23.88 & & \\
\hline & 19 & 90 & 67.16 & & \\
\hline & 20 and older & 12 & 8.96 & & \\
\hline & Younger than 30 & & & 14 & 28.57 \\
\hline & $31-40$ & & & 27 & 55.10 \\
\hline & 41 and older & & & 6 & 12.25 \\
\hline & No answer & & & 2 & 4.08 \\
\hline Race & African & 15 & 11.19 & & \\
\hline & Coloured & 28 & 20.90 & 7 & 14.29 \\
\hline & White & 80 & 59.70 & 42 & 85.71 \\
\hline & Other & 7 & 5.22 & & \\
\hline
\end{tabular}




\begin{tabular}{|c|c|c|c|c|c|}
\hline \multirow{2}{*}{ Category } & \multirow{2}{*}{ Options } & \multicolumn{2}{|c|}{ Focus Group 1} & \multicolumn{2}{|c|}{ Focus Group 2} \\
\hline & & $\mathbf{n}$ & $\%$ & $\mathbf{n}$ & $\%$ \\
\hline & No answer & 4 & 2.99 & & \\
\hline \multirow[t]{3}{*}{ Home Language } & Afrikaans & 48 & 35.82 & 42 & 85.71 \\
\hline & English & 70 & 52.24 & 7 & 14.29 \\
\hline & Other & 16 & 11.94 & & \\
\hline \multirow[t]{6}{*}{ Time as lecturer } & Less than 2 years & & & 12 & 24.49 \\
\hline & $2-3$ years & & & 6 & 12.24 \\
\hline & $4-5$ years & & & 6 & 12.24 \\
\hline & $6-10$ years & & & 12 & 24.49 \\
\hline & More than 10 years & & & 12 & 24.49 \\
\hline & No answer & & & 1 & 2.04 \\
\hline \multirow[t]{6}{*}{ Self-rated technological skills } & 1 & 49 & 36.57 & 13 & 26.53 \\
\hline & 2 & 50 & 37.31 & 23 & 46.94 \\
\hline & 3 & 23 & 17.16 & 10 & 20.41 \\
\hline & 4 & 2 & 1.49 & & \\
\hline & 5 & 1 & 0.75 & & \\
\hline & No answer & 9 & 6.72 & 3 & 6.12 \\
\hline
\end{tabular}

\section{Research Question 1: Do students and lecturers have different opinions on the matters affected by the live streaming of lectures?}

Both focus groups were given the same set of statements in Likert-scale format. An F-test was done and the results of the two groups were compared to determine whether a significant difference existed between them. The results are summarised in Table 3. Both groups agreed strongly with the statement that class attendance plays a big role in students achieving academic success, therefore confirming the results of Fraser and Killen (2003, 257). Students supported their answer in the Likert-scale statement when 129 of the participants (96.27\%) confirmed that they attend more than 80 per cent of their accounting lectures. If students are therefore prevented from attending class (for whichever reason), their academic achievement could be in jeopardy.

Table 3: Comparisons between student and lecturer opinions

\begin{tabular}{|c|c|c|c|c|c|c|}
\hline \multirow[b]{2}{*}{ Likert-scale question } & \multicolumn{2}{|c|}{ Focus Group 1} & \multicolumn{2}{|c|}{ Focus Group 2} & \multirow[b]{2}{*}{$\mathbf{F}$} & \multirow[b]{2}{*}{$\underset{\text { p-value }}{F}$} \\
\hline & Average & $\begin{array}{l}\text { Standard } \\
\text { deviation }\end{array}$ & Average & $\begin{array}{l}\text { Standard } \\
\text { deviation }\end{array}$ & & \\
\hline $\begin{array}{l}\text { I believe class attendance plays a big } \\
\text { role in me/students achieving } \\
\text { academic success. }\end{array}$ & 4.21 & 0.97 & 4.44 & 0.90 & 2.05 & 0.15 \\
\hline $\begin{array}{l}\text { I/Students find it difficult to attend all } \\
\text { lectures due to personal } \\
\text { circumstances and/or timetable } \\
\text { clashes. }\end{array}$ & 2.16 & 1.20 & 2.61 & 0.95 & 5.57 & 0.02 \\
\hline $\begin{array}{l}\text { I/Students would prefer all my/their } \\
\text { lectures to be streamed with no } \\
\text { physical class attendance. }\end{array}$ & 2.56 & 1.18 & 2.31 & 0.95 & 1.65 & 0.20 \\
\hline $\begin{array}{l}\text { I/Students would prefer a mix of } \\
\text { physical class attendance and } \\
\text { streaming. }\end{array}$ & 3.75 & 1.14 & 3.73 & 0.96 & 0.02 & 0.90 \\
\hline
\end{tabular}




\begin{tabular}{|c|c|c|c|c|c|c|}
\hline \multirow[b]{2}{*}{ Likert-scale question } & \multicolumn{2}{|c|}{ Focus Group 1} & \multicolumn{2}{|c|}{ Focus Group 2} & \multirow[b]{2}{*}{$\mathbf{F}$} & \multirow{2}{*}{$\begin{array}{c}F \\
p-v a l u e\end{array}$} \\
\hline & Average & $\begin{array}{l}\text { Standard } \\
\text { deviation }\end{array}$ & Average & $\begin{array}{l}\text { Standard } \\
\text { deviation }\end{array}$ & & \\
\hline $\begin{array}{l}\text { I/Students speak to their lecturer or } \\
\text { ask questions during and/or directly } \\
\text { after class. }\end{array}$ & 2.80 & 1.10 & 4.06 & 0.84 & 51.57 & $<0.01$ \\
\hline $\begin{array}{l}\text { My/Students' marks would improve if } \\
\text { I/they could have the option of } \\
\text { streaming classes. }\end{array}$ & 3.14 & 1.04 & 3.00 & 0.94 & 0.71 & 0.40 \\
\hline $\begin{array}{l}\text { Not attending physical lectures will } \\
\text { have a negative influence on my/a } \\
\text { student's ability to make friends or } \\
\text { connect with other students on } \\
\text { campus. }\end{array}$ & 2.91 & 1.29 & 3.67 & 0.94 & 14.34 & $<0.01$ \\
\hline $\begin{array}{l}\text { The classroom is currently } \\
\text { overcrowded and it negatively affects } \\
\text { my/students' ability to concentrate } \\
\text { during lectures. }\end{array}$ & 2.50 & 1.11 & 2.57 & 1.02 & 0.16 & 0.69 \\
\hline
\end{tabular}

The only two significant differences reported between Focus Group 1 and 2 related to students' level of interaction with their lecturer during and/or after class, and the effect of not attending classes physically on students' ability to make friends. Focus Group 2 is more likely to agree with the statement that students tend to interact with their lecturer, whereas students lean towards disagreeing with this statement. If students are not inclined to interact with their lecturer in class, they may prefer to stream the class from home. Focus Group 2 was also more likely to agree that not attending lectures physically will have a negative influence on students' ability to socialise with their peers. Focus Group 1 was more likely to disagree with this statement. Students therefore may not perceive classes (or the attendance of lectures) as the only space where they socialise with other students. According to them, live streaming should therefore not impact their ability to interact with other students.

None of the other statements reported a significant difference between the two focus groups. Both groups leaned towards disagreeing with the statement that students might find it difficult to attend all their lectures due to personal circumstances or timetable clashes. A mix of physical classes and live streaming seems to be preferred by both focus groups above solely live-streaming classes. The groups both reported fairly neutral responses towards the statement of marks improving as a result of live-streamed lectures. Lastly, participants at Stellenbosch University do not believe that their classes are overcrowded. Other reasons may therefore apply for the introduction of live-streaming facilities at this institution.

\section{Research Question 2: What do students and lecturers perceive as the most important factors that contribute to a student's decision for or against the live streaming of lectures?}

Participants from both focus groups were presented with the same set of arguments in favour 
of live streaming and the same set of arguments against it. Eight arguments for and eight arguments against live streaming of lectures were presented. The arguments listed in the questionnaires were based on the literature review and the researcher's limited practical arguments explored. The results for arguments in favour of live streaming of lectures are summarised in Table 4 and the results for arguments against it in Table 5. Both tables are prepared according to the results of the average ranking order of Focus Group 1. The results were analysed in two ways: first in terms of the ranking position of the statement and secondly in terms of the difference (whether significant or not) in the mean rating between the two groups.

Table 4: Arguments in favour of live streaming

\begin{tabular}{|l|c|c|c|c|c|}
\hline \multirow{2}{*}{ Arguments } & \multicolumn{2}{|c|}{ Ranking } & \multicolumn{2}{c|}{ Mean } & \multirow{2}{*}{ p-value } \\
\cline { 2 - 5 } & $\begin{array}{c}\text { Focus } \\
\text { Group 1 }\end{array}$ & $\begin{array}{c}\text { Focus } \\
\text { Group 2 }\end{array}$ & $\begin{array}{c}\text { Focus } \\
\text { Group 1 }\end{array}$ & $\begin{array}{c}\text { Focus } \\
\text { Group 2 }\end{array}$ & \\
\hline Convenience of own space & 1 & 1 & 2.96 & 2.55 & 0.25 \\
\hline Focus better when alone & 2 & 3 & 3.98 & 3.02 & $<0.01$ \\
\hline Boring class & 3 & 5 & 4.37 & 4.21 & 0.65 \\
\hline Location, i.e. living far from campus & 4 & 2 & 3.50 & 4.79 & $<0.01$ \\
\hline Overcrowded classes & 5 & 6 & 4.98 & 4.93 & 0.90 \\
\hline Timetable clash & 6 & 4 & 4.16 & 5.59 & $<0.01$ \\
\hline Dislike lecture venue & 7 & 8 & 6.09 & 5.70 & 0.12 \\
\hline Dislike lecturer & 8 & 7 & 6.09 & 6.65 & 0.27 \\
\hline
\end{tabular}

Both focus groups ranked "convenience of own space" as the most popular argument why students would make use of live-streaming facilities (Table 4) and "data is expensive" as their most popular argument why students would not make use of live streaming (Table 5). Significant differences were reported for three of the arguments "for" the live streaming of lectures. The arguments with significant differences are "focus better when alone", "location" and "timetable clashes". "Focus better when alone" was ranked by Focus Group 1 as the second most popular argument, while Focus Group 2 listed this argument as third. If "better focus" could translate to "better results," then live-streaming should definitely be promoted at tertiary institutions. The matter of focus is dependent on each individual's style of learning. The results do seem to show that the majority of students feel that they would focus better when they are alone.

"Location" and "timetable clashes" also showed a significant difference in ranking between the two focus groups. Both arguments were ranked higher by Focus Group 2. These two items were initially included in the study as practical arguments in favour of live streaming. It can therefore be deduced that lecturers perceive these practicalities as affecting class attendance more than may actually be true. Other arguments for live-streaming facilities as 
listed by Focus Group 1 included:

"Maybe if the lessons could be recorded and saved so I can watch them later when revising."

"If I feel sick I can stream the class instead of having to go to class."

"In case there are no lecturers in a particular day due to an unfavourable event."

The comments from Focus Group 1 are underlined by the comments made by Focus Group 2:

"Ability to learn at their own pace (if lectures can be paused)."

"When they are ill. They can probably also record the lecture electronically, so if it is a subject they struggle with they can record it to assist them later (I am unsure if the lecture will be made available afterwards, so this is an option to consider)."

It is clear from the additional comments that students and lecturers feel that live-streamed classes should be recorded and made available afterwards. These comments align strongly with comments made by participants from the study conducted by Wall Parilo and Parsh (2014).

Table 5: Arguments against live streaming

\begin{tabular}{|l|c|c|c|c|c|}
\hline \multirow{2}{*}{\multicolumn{1}{c|}{ Argument }} & \multicolumn{2}{c|}{ Ranking } & \multicolumn{2}{c|}{ Mean } & \multirow{2}{*}{ p-value } \\
\cline { 2 - 6 } & $\begin{array}{c}\text { Focus } \\
\text { Group 1 }\end{array}$ & $\begin{array}{c}\text { Focus } \\
\text { Group 2 }\end{array}$ & $\begin{array}{c}\text { Focus } \\
\text { Group 1 }\end{array}$ & $\begin{array}{c}\text { Focus } \\
\text { Group 2 }\end{array}$ & 0.11 \\
\hline Data is expensive & 1 & 1 & 3.85 & 3.22 & 0.85 \\
\hline Technology failure & 2 & 4 & 4.27 & 4.35 & 0.29 \\
\hline Internet connectivity & 3 & 2 & 4.29 & 3.86 & 0.34 \\
\hline Prefer personal contact with lecturer & 4 & 3 & 4.33 & 3.95 & 0.84 \\
\hline Social aspect (going to class with friends) & 5 & 5 & 4.64 & 4.56 & 0.09 \\
\hline Focus better in class & 6 & 8 & 4.83 & 5.51 & 0.78 \\
\hline Cannot pause live streaming & 7 & 6 & 5.07 & 5.18 & 0.99 \\
\hline Questions go unanswered & 8 & 7 & 5.19 & 5.19 & \\
\hline
\end{tabular}

There were no significant differences between the responses of the two focus groups on arguments "against" live streaming as summarised in Table 5. The two arguments that were included as practicalities, "data is expensive" and "internet connectivity", were listed by both groups as two of the top three arguments.

Focus Group 1, being students, were also asked in the questionnaire whether they would make use of live-streaming facilities at all. Of the 121 respondents who answered this question, $108(89.26 \%)$ said "yes". Similar to the previous question, Focus Group 1 was also asked whether they would make use of live-streaming facilities if they were guaranteed that it would work 100 per cent (in other words no technical failures or problems with connectivity). There were 125 responses for this question, of which 112 (89.6\%) responded "yes". It is interesting 
to find that there is very little difference in the responses to these questions. The arguments listed "against" live-streaming facilities therefore do not seem to deter students' willingness to make use of it. The following arguments against live-streaming facilities were added by both groups:

"The video isn't uploaded onto (the student learning platform) after it has been streamed. It would help to be able to go back and watch the videos again if need be."

"Seeing other people working motivates me to work too."

"Going to class 'forces' you to look at the work ... at home you can postpone it."

The additional comments added by participants reveal the reality that the choice for live streaming a class would depend on the individual. Some students focus better when they are alone, while others need the academic environment to concentrate on academic activities. Recording the live-streamed classes and making it available to students afterwards were emphasised again.

\section{Research Question 3: Is there a relationship between participants' self-rated technological level and their willingness to make use of live-streaming facilities?}

The literature shows conflicting results regarding students' self-rated level of technological ability and their satisfaction with a course. The available studies all focused on technological ability and level of satisfaction. Seeing as this study targeted SU, a campus where live streaming is not yet considered an established practice, the focus was shifted to comparing self-rated technological ability with willingness to partake in live-streaming facilities, rather than satisfaction levels with a particular course or respondents' experience of the facility. The results would be helpful in establishing whether live streaming would be a viable alternative to physical classes for tertiary institutions where live streaming is not yet considered common practice, especially in times of unrest on campus.

The results of this study showed no significant difference in the interaction between the two focus groups' response to the question of whether students would make use of livestreaming facilities $(p=0.38)$. The results of the two groups could therefore be combined. The answer (on whether students would make use of live-streaming facilities or not) was compared to students' level (and perceived level as reported by lecturers) of technological skills. This result did show a significant difference $(\mathrm{p}<0.01)$ and supports the studies by Sahin and Shelley (2008) and Owens, Hardcastle and Richardson (2009). Students who would make use of livestreaming facilities rated their own technological ability much better than students who would 
not use it. This leads to the conclusion that students with a lower self-rated technology level would rather attend class physically than watch a live-streamed lecture from home.

Focus Group 2 were also asked whether they would volunteer to live-stream their classes. This was not a compulsory question and only 41 responses (of the 49 participants) were obtained. Of the 41 responses, 40 participants also gave their age at the biographical information, and therefore the results of the 40 respondents were analysed per age group and summarised in Table 6. Approximately half (52.5\%) of the respondents would volunteer to stream their classes. The majority $(69.23 \%)$ of respondents who are 30 years and younger would volunteer to stream their classes, while the majority (61.90\%) between the age of 31 and 40 would not want to volunteer for their classes to be live-streamed.

Table 6: Focus Group 2's willingness to live stream their classes

\begin{tabular}{|l|c|c|c|}
\hline \multicolumn{1}{|c|}{ Age } & Yes & No & Total \\
\hline 30 and younger & 9 & 4 & $\mathbf{1 3}$ \\
\hline 31 to 40 & 8 & 13 & $\mathbf{2 1}$ \\
\hline 41 and older & 4 & 2 & $\mathbf{6}$ \\
\hline & $\mathbf{2 1}$ & $\mathbf{1 9}$ & \\
\hline
\end{tabular}

Some of the comments from lecturers who would not volunteer for their classes to be streamed included the following:

"I have made extensive use of podcasts to capture main concerns and find it a good compromise. I feel uncomfortable with the idea of streaming lectures as I feel that class attendance is one of reasons you would want to come and study at Stellenbosch. I am concerned about how I would come across on a streaming solution. I would also miss the interaction with the students. I am weary of students that might become 'lost' in the system should they be provided with this option. Having said that, I am aware that some students might find it very beneficial."

"Research has proven that class attendance leads to academic success."

It was, however, interesting to find no significant difference $(p=0.84)$ between Focus Group 2's willingness to volunteer for their classes to be live-streamed and their self-rated technological ability. This leads to the conclusion that their opinion on whether they are willing to stream their classes has more to do with their style and beliefs regarding teaching and less with their own confidence or insecurity regarding a new technology being introduced to the teaching and learning environment.

\section{CONCLUSION}

This study originated when the need arose to investigate alternative options (where they do not necessarily exist yet) for physical class attendance in times where student numbers are rapidly 
increasing and a substitute is needed for physical class attendance in times of unrest on campus. Live-streaming lectures provide such an alternative and/or substitute to physical classes. The objective of this research was to investigate student and lecturer perceptions on the live streaming of lectures. Three research questions were formulated and questionnaires were used to obtain the necessary data from the two focus groups (i.e. students and lecturers).

First, the opinions of students and lecturers were compared on matters specifically pertaining to live streaming. The same questions were asked to both groups of participants in Likert-scale format. Both groups agreed strongly that class attendance plays a big role in students achieving academic success, confirming the findings of Fraser and Killen $(2003,257)$ and Van Schalkwyk, Menkveld and Ruiters $(2010,634)$. It is therefore crucial for the teaching functionality to continue at all times. Whether a student attends class physically or via live streaming might therefore be irrelevant, as long as the student hears the message in some way. Two significant differences were reported between the two groups. Lecturers agreed with the statements that students interact with them during or after class and that students' ability to connect with other students will be impeded if they do not attend class physically. In both cases student participants leaned towards disagreeing with these statements. They do not seem to believe that they interact with lecturers that much and do not think that live streaming will affect their ability to make friends on campus.

Another aim of this study was to investigate what students would perceive to be arguments for or against the live streaming of lectures. Both groups agreed that the convenience of their own space would be the most popular argument for students to make use of live-streaming facilities, while the high cost of data would be the most popular argument why they would not use it. Only three significant differences between the two focus groups were reported. All three differences related to arguments for live streaming. Students placed "focus better when alone" as a higher ranked argument than lecturers. Lecturers, on the other hand, placed "location" and "timetable clashes" higher up in the ranking than students. From the additional comments made by both groups, it became clear that there is a need for live-streamed lectures to be recorded and made available to students afterwards.

Lastly, it was investigated whether there is a correlation between participants' self-rated technological ability and their willingness to make use of live-streaming facilities. A significant difference was reported: students who are willing to make use of live-streaming facilities have a higher self-rated level of technological ability than students who would not make use of it. Lecturers were also asked whether they would volunteer for their classes to be live-streamed. Approximately half of the lecturers who participated would volunteer, while the other half would not. However, lecturers' willingness to stream their classes does not have anything to do 
with their self-rated technological ability, but rather their own beliefs or preference regarding teaching and learning.

The rise in student numbers can, to an extent, be managed. It cannot, however, be predicted whether unrest on campuses will flare up again. This study shows that live-streaming lectures will definitely be welcomed by students should it be implemented as an alternative or as a substitute to physical class attendance.

It should be noted that this study only includes the perceptions of first-year accounting students and lecturers from one faculty at one university. Their views could be different from students in other fields of study and from other universities based on their needs in their specific field of study.

\section{REFERENCES}

Abdous, M. and C. Yen. 2010. A predictive study of learner satisfaction and outcomes in face-to-face, satellite broadcast, and live video-streaming learning environments. The Internet and Higher Education 13(4): 248-257.

Anon. 2016. Student protests shut down universities. Servamus Community-based Safety and Security Magazine 109(1): 25-27.

Bollinger, D. U. and T. Martindale. 2004. Key factors for determining student satisfaction in online courses. International Journal on E-Learning 3(1): 61-67.

Cloete, N. 2015. The flawed ideology of "free higher education". http://www.universityworldnews.com/ article.php?story=20151104111825416 (Accessed 6 October 2017).

De Villiers, W. 2017. Building bridges between the online and offline worlds. University World News. May 26, Issue 461. http://www.universityworldnews.com/article.php?story=2017052323 1744555 (Accessed 10 August 2017).

Department of Higher Education and Training. 2017. 2000 to 2014 First time entering undergraduate cohort studies for public higher education institutions. http://www.dhet.gov.za/ HEMIS/2000\%20TO\%202014\%20FIRST\%20TIME\%20ENTERING\%20UNDERGRADUATE \%20COHORT\%20STUDIES\%20FOR\%20PUBLIC\%20HEIs\%20(final).pdf

DHET see Department of Higher Education and Training.

Fraser, W. J. and R. Killen. 2003. Factors influencing academic success or failure of first-year and senior university students: Do education students and lecturers perceive things differently? South African Journal of Education 23(4): 254-263.

Fredriksen, H. 2015. A case study of an experiment using streaming of lectures in teaching engineering mathematics. Teaching Mathematics and Its Applications 34(1): 44-52.

Gerber, C., N. Mans-Kemp and A. Schlechter. 2013. Investigating the moderating effect of student engagement on academic performance. Acta Academica 45(4): 256-274.

Hill, M. C. and K. K. Epps. 2010. The impact of physical classroom environment on student satisfaction and student evaluation of teaching in the University environment. Academy of Educational Leadership Journal 14(4): 65-79.

Koroghlanian, C. M. and J. Brinkerhoff. 2008. Online students' technology skills and attitudes toward online instruction. Journal of Educational Technology Systems 36(2): 219-244.

Mokoena, S. 2011. Student perspectives on videoconferencing in teacher education at a distance. Progressio 33(2): 136-150. 
Owens, J., L. Hardcastle and B. Richardson. 2009. Learning from a distance: The experience of remote students. Journal of Distance Education 23(3): 53-74.

Sader, S. B. and N. P. Gabela. 2017. Spatialities of widening participation: Narratives of first year students receiving financial aid. South African Journal of Higher Education 31(1): 227-242.

Sahin, I. and M. Shelley. 2008. Considering students' perceptions: The distance education student satisfaction model. Educational Technology \& Society 11(3): 216-223.

Stellenbosch University. 2015. Faculty of Economic and Management Sciences integrated annual report 2015. http://www.sun.ac.za/english/faculty/economy/_layouts/15/WopiFrame.aspx? sourcedoc= \%7B95162827-dd5e-41d9-8b0b-acd3c10d64a2\%7D\&action=default (Accessed 26 September 2017).

Stellenbosch University. 2016. Faculty of Economic and Management Sciences integrated annual report 2016. http://www.sun.ac.za/english/faculty/economy/Documents/EMS_Annual_Report_ 2016.pdf (Accessed 26 September 2017).

Van Schalkwyk, S., H. Menkveld and J. Ruiters. 2010. What's the story with class attendance? Firstyear students: Statistics and perspectives. South African Journal of Higher Education 24(4): 630645.

Wall Parilo, D. M. and B. Parsh. 2014. Case study: Student perceptions of video streaming nursing class sessions. Journal of Nursing Education 53(3): 161-164.

Webster, T. E. and J. Son. 2015. Doing what works: A grounded theory case study of technology use by teachers of English at a Korean university. Computers \& Education 80: 84-94.

Weidemann, R. 2016. The student accountant conundrum. Professional Accountant 2016(28): 6-9.

Wilson, H., R. Schenck and H. Grobler. 2000. Video conferencing in Unisa social work practicals: Structure and strategies. Progressio 22(1): 88-98. 